\title{
ISOLATION OF YELLOW FEVER VIRUS (YFV) FROM NATURALLY INFECTED Haemagogus (Conopostegus) leucocelaenus (DIPTERA, CULICIDAE) IN SÃO PAULO STATE, BRAZIL, 2009
}

\author{
Renato Pereira de SOUZA(1), Selma PETRELLA(1), Terezinha Lisieux Moraes COIMBRA(1), Adriana Yurika MAEDA(1), Iray Maria ROCCO(1), Ivani BISORDI(1), \\ Vivian Regina SILVEIRA(1), Luiz Eloy PEREIRA(1), Akemi SUZUKI(1), Sarai Joaquim dos Santos SILVA(1), Fernanda Gisele SILVA(1), \\ Felipe Scassi SALVADOR(1), Rosa Maria TUBAKI(2), Regiane Tironi MENEZES(2), Mariza PEREIRA(2), Eduardo Sterlino BERGO(2), \\ Roberto Colozza HOFFMANN(3), Roberta Maria Fernandes SPINOLA(4), Cílea Hatsumi TENGAN(4) \& Melissa Mascheratti SICILIANO(4)
}

\begin{abstract}
SUMMARY
After detecting the death of Howlers monkeys (genus Alouatta) and isolation of yellow fever virus (YFV) in Buri county, São Paulo, Brazil, an entomological research study in the field was started. A YFV strain was isolated from newborn Swiss mice and cultured cells of Aedes albopictus - C6/36, from a pool of six Haemagogus (Conopostegus) leucocelaenus (Hg. leucocelaenus) mosquitoes (Dyar \& Shannon) collected at the study site. Virus RNA fragment was amplified by RT-PCR and sequenced. The MCC Tree generated showed that the isolated strain is related to the South American I genotype, in a monophyletic clade containing isolates from recent 20082010 epidemics and epizootics in Brazil. Statistical analysis commonly used were calculated to characterize the sample in relation to diversity and dominance and indicated a pattern of dominance of one or a few species. Hg. leucocelaenus was found infected in Rio Grande do Sul State as well. In São Paulo State, this is the first detection of YFV in Hg. leucocelaenus.
\end{abstract}

KEYWORDS: Yellow fever; Haemagogus leucocelaenus; Arbovirus.

\section{INTRODUCTION}

Yellow Fever (YF) is an endemic disease in South America and Africa, affecting about 200,000 people yearly ${ }^{16}$.

In São Paulo State, Brazil, YF first appeared in Santos county. From 1850 onward, the city was hit by constant outbreaks of the disease, introduced by the crew of newly arrived ships, spreading from the port region $^{23}$. In 1889 there was a strong epidemic in Santos county, moving towards the west and reaching as far as the county of Campinas, which was successively affected by epidemics in 1889, 1890, 1892, 1896 and $1897^{18}$. The 1895-1898 outbreaks affected Araraquara county, and in 1898 and 1904, there were epidemics in cities in the western region of the São Paulo State ${ }^{18,23}$. The last reported case of Sylvan YF (SYF) in São Paulo State was in $1953^{23}$ and it remained so up to 2000 , when the disease reemerged in São Paulo State, after a period of 49 years ${ }^{19}$. The last reported case of Urban Yellow Fever (UYF) in Brazil was in 1942, in Sena Madureira county, Acre State ${ }^{15}$.

Sylvan Yellow Fever has remained endemic in Northern Brazil ever since, with epidemics and epizootic occurrences sporadically detected in the Midwest region and more rarely in the Southeast ${ }^{14}$. After this period, and considering the epidemics in the years 2008 and 2009, the virus, once considered endemic in only a limited portion of the country, started to be detected in almost all Brazilian territory, and so far only the coastal region is still considered to be free of transmission ${ }^{26}$.

The SYF has been gradually expanding its territory, which led to a gradual increase in cases near the traditional boundaries of the enzootic area, as well as in the states of Rio Grande do Sul ${ }^{9}$ and Minas Gerais in 2000 and 2001, respectively ${ }^{8}$. The high mobility of human populations in such regions of transmission, associated with the spread of the Aedes aegypti in Brazil2 ${ }^{25}$, represents a real risk for the reintroduction of YFV in the urban environment.

In 2000 two autochthonous SYF cases were registered in the State of São Paulo, along the border of Minas Gerais State ${ }^{19}$. The environmental circumstances in which transmission occurred were not elucidated. In 2008 the circulation of YFV in São Paulo State was confirmed in the region of São Jose do Rio Preto county. The YFV was recovered from four primates of the genus Alouatta and from a pool of mosquitoes Ps. ferox. In the Ribeirão Preto region, two autochthonous human cases were confirmed in Luiz Antônio and São Carlos counties by virus isolation and immunohistochemistry, respectively.

(1) Núcleo de Doenças de Transmissão Vetorial, Instituto Adolfo Lutz, Secretaria de Estado da Saúde de São Paulo, (IAL/SES/SP), São Paulo, SP, Brasil.

(2) Superintendência de Controle de Endemias (SUCEN-SES-SP), São Paulo, SP, Brasil.

(3) Centro de Controle de Zoonoses "Enfa. Carmen L. Paione"- Prefeitura de São João da Boa Vista, (CCZ/SJBV/SP), São João da Boa Vista, SP, Brasil.

(4) Centro de Vigilância Epidemiológica "Prof. Alexandre Vranjac" (CVE/CCD/SES-SP), São Paulo, SP, Brasil.

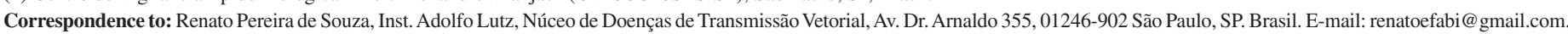




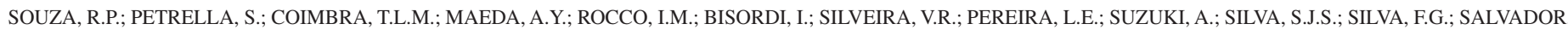
F.S.; TUBAKI, R.M.; MENEZES, R.T.; PEREIRA, M.; BERGO, E.S.; HOFFMANN, R.C.; SPINOLA, R.M.F.; TENGAN, C.H. \& SICILIANO, M.M. - Isolation of Yellow Fever Virus (YFV) from naturally infected Haemagogus (Conopostegus) leucocelaenus (Diptera, Culicidae) in Sao Paulo State, Brazil, 2009. Rev. Inst. Med. Trop. Sao Paulo, 53(3): 133-9, 2011.

In 2009, epidemics and epizootics were detected in the Southwest region of São Paulo State, in the counties of Sarutaiá, Avaré, Buri, Piraju and Tejupá. In Buri county, five human cases and one non-human primate positive for YFV were detected (unpublished data). This study describes the results obtained during the entomological survey that followed the detection of YF epidemics in Buri, State of Sao Paulo.

\section{MATERIAL AND METHODS}

Study Area: The study was conducted in Enchovias District $\left(23^{\circ}\right.$ 42' S 108 - 48 41' W 174) located in Buri county, São Paulo, Brazil. Buri is located $270 \mathrm{Km}$ from São Paulo city, at an altitude of 590 meters. The climate is temperate and the mean annual temperature is $20{ }^{\circ} \mathrm{C}$ (Fig. 1).
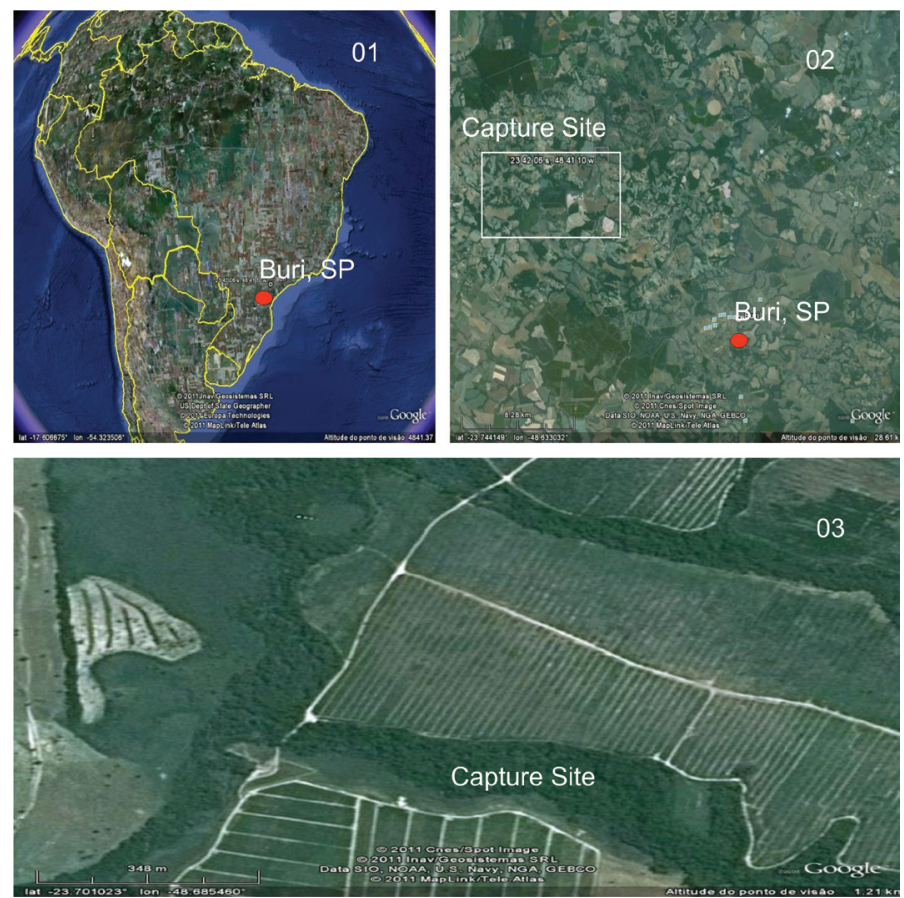

Fig. 1 - Map of the Study Area: 01. Location of Buri county in Brazil. 02. Capture Site in relation to Buri county. 03. Capture site, with forest areas near by farmlands and grazing pastures used for cattle ranching. We can see the intensely patchy and irregular distribution of natural vegetation. Images from Google Earth 6.0. (2011 Inav Geossistemas. US Dept. State Geographer. (C2011 Europa Technologies. (C2011 MapLink/Teleatlas.

The region is characterized by the presence of forested areas covered by the native vegetation of typical Atlantic Rainforest, strongly affected by human action. The forest areas border farmlands and grazing pastures used for cattle ranching, and it is intensely patchy and irregularly distributed.

Mosquito capture: Mosquito capture occurred from 11 to 13 April, 2009. Mosquitoes were collected at ground level, with the aid of dip nets and oral suction capturing devices. The capture was conducted inside forest fragments, along a transect in the area. Technicians (all of whom had been previously immunized against YF) moved for 15 minutes and stopped for one hour to perform the capture and then moved again. The capture process occurred between 09:30 am and 4:00 pm.
The collected mosquitoes were immobilized by freezing and were transported in liquid nitrogen and stored in freezers $\left(-70{ }^{\circ} \mathrm{C}\right)$ in the laboratory, until species identification and isolation of the virus were conducted.

Virus isolation in mice: The mosquitoes collected in the same place, date and time were processed in pools of one to 50 individuals separated by species or, in cases in which the definition of species was not possible, the same genus. Pool size was determined by the size of the mosquitoes and quantity of specimens. Pools of mosquitoes were grounded and suspended in $2 \mathrm{~mL}$ of phosphate buffer with $1.8 \%$ bovine serum albumin, containing $100 \mathrm{U} / \mathrm{mL}$ of penicillin and $100 \mu \mathrm{L}$ of streptomycin. Each suspension, after centrifugation, was inoculated by the intracerebral route in six newborn Swiss mice at a dose of $0.02 \mathrm{~mL} /$ mouse. The animals were observed over the course of 14 days. Brains of sick mice were ground and suspended in $2 \mathrm{~mL}$ of phosphate buffer with $0.75 \%$ bovine serum albumin, containing $100 \mathrm{U} / \mathrm{mL}$ of penicillin and $100 \mu \mathrm{L}$ of streptomycin and subsequently inoculated into new mice and processed by reverse transcriptase-polymerase chain reaction (RT-PCR) $)^{2,25}$.

Virus isolation in cell culture: Twenty microliters of suspensions from the mosquito pools (see protocol for virus isolation in mice) were inoculated in tubes seeded with cultured cells of Aedes albopictus, clone C6/36 ${ }^{12}$. After nine days at $28^{\circ} \mathrm{C}$, the cell cultures were shaken, centrifuged and the pellets of cells were resuspended in PBS pH 7.5. Indirect immunofluorescence assay (IFA) using polyclonal anti-yellow fever antibodies ${ }^{4}$ and anti-mouse immunoglobulin conjugated (fluorescein isothiocyanate - Sigma) were performed. Positive samples were typed by IFA with monoclonal antibodies to YFV (Centers for Disease Control and Prevention).

RNA extraction and RT-PCR: Total RNA was extracted from supernatant fluid of C6/36 and tissue (brain and liver) of suckling Swiss mice infected with suspension of mosquitoes, using commercial kits QIAamp® Viral RNA and QIAamp® RNA Blood (Qiagen Inc., Ontario, $\mathrm{CA})$, respectively, according to the manufacturer's instructions.

The amplification of viral RNA was carried out as described previously ${ }^{5}$ with some modifications. RT-PCR one step was performed with SuperScript ${ }^{\mathrm{TM}}$ and Platinum ${ }^{\circledR}$ (Invitrogen/Life Technologies, Carlsbad, CA), followed by a second amplification (semi-nested), from the products of the first reaction, diluted at 1:50. Other conditions, including the cycle program, were identical. The target region was the NS5-3'UTR of the Yellow Fever virus. The amplified products (expected to be approximately $542 \mathrm{bp}$ ) were visualized by electrophoresis in $1.7 \%$ agarose gel stained with ethidium bromide.

Sequencing: The purified PCR products were directly sequenced on $\mathrm{ABI} 377$ sequencer, using the BigDye terminator sequencing kit v.3.1 (Applied Biosystems, Foster City, CA), following exactly the manufacturer's instructions with the same pair of primers from the one step RT-PCR.

For the edition of the nucleotide sequences, the Chromas Lite v.2.01 (Technelysium Pty Ltd.) was used, excluding the sequences of the primers.

Phylogenetic analysis: Sequences representative of the genotypes South American I, South America II, East Africa and West Africa were 


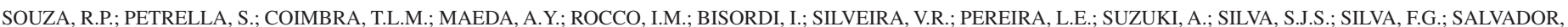

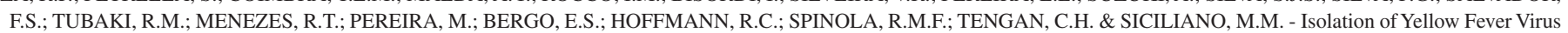
(YFV) from naturally infected Haemagogus (Conopostegus) leucocelaenus (Diptera, Culicidae) in Sao Paulo State, Brazil, 2009. Rev. Inst. Med. Trop. Sao Paulo, 53(3): 133-9, 2011.

Table 1

3'NCR sequences used in this study

\begin{tabular}{|c|c|c|c|c|}
\hline Isolate & Sequence ID & Origin/Year of Isolation & Source & Genbank No \\
\hline Asibi & Ghana27 & Ghana/1927 & Human & AY326411 \\
\hline Senegal65 & Senegal65 & Senegal/1965 & Human & U52414 \\
\hline 69056 & Nigeria46 & Nigeria/1946 & Human & U52403 \\
\hline H117505 & Nigeria87C & Nigeria/1987 & Human & AY541410 \\
\hline Serie 227 & Ethiopia61A & Ethiopia/1961 & Human & AY541407 \\
\hline Uga & Uganda48 & Uganda48 & Human & U52423 \\
\hline $85-82 \mathrm{H}$ & IvoryC85 & Ivory Coast/1982 & Human & U54798 \\
\hline Ar B 8883 & CAR77A & Central African Republic/1977 & Aedes africanus & U52393 \\
\hline Ar B 9005 & CAR77B & Central African Republic/1977 & Aedes africanus & U52396 \\
\hline Trinidad79 & Trinidad79 & Trinidad/1979 & Hg. spegazzini & U52420 \\
\hline $1899 / 81$ & Peru81 & Peru/1981 & Human & U52411 \\
\hline Peru95 & Peru95 & Peru/1995 & Human & U52407 \\
\hline OBS7687 & Bolivia99A & Bolivia/1999 & Human & AY541326 \\
\hline OBS8026 & Bolivia99D & Bolivia/1999 & Human & AY541327 \\
\hline BeH203416 & Brazil71 & Brazil/1971 & Human & AY541344 \\
\hline JSS & Brazil35 & Brazil/1935 & Human & U52390 \\
\hline SPH188002 & Brazil00B & $\mathrm{SP} / 2000$ & Human & FJ875521 \\
\hline SPH287923 & Brazil08A & MT/2008 & Human & FJ875524 \\
\hline SPH287992 & Brazil08B & $\mathrm{MS} / 2008$ & Human & FJ875525 \\
\hline SPH288116 & Brazil08C & $\mathrm{GO} / 2008$ & Human & FJ875526 \\
\hline SPH258595 & Brazil04 & $\mathrm{AM} / 2004$ & Human & FJ875523 \\
\hline SPAn288183 & Brazil08E & $\mathrm{SP} / 2008$ & Alouatta $\mathrm{sp}$ & FJ875528 \\
\hline BeAR628124 & Brazil00A & Brazil/2000 & Hg. janthinomys & AY541328 \\
\hline BeAr645693 & Brazil01D & Brazil/2001 & Haemagogus sp & AY541334 \\
\hline BeH605427 & Brazil98E & Brazil/1998 & Human & AY541398 \\
\hline BeH603325 & Brazil98D & Brazil/1998 & Human & AY541397 \\
\hline BeAn604552 & Brazil98A & Brazil/1998 & Alouatta belzebul & AY541394 \\
\hline BeAr512943 & Brazil92C & Brazil/1992 & Hg. janthinomys & AY541379 \\
\hline BeH511843 & Brazil91B & Brazil/1991 & Human & AY541377 \\
\hline BeH422312 & Brazil84H & Brazil/1984 & Human & AY541369 \\
\hline BeAr424492 & Brazil84E & Brazil/1984 & Hg. janthinomys & AY541366 \\
\hline ВеH350698 & Brazil78A & Brazil/1978 & Human & AY541352 \\
\hline BeH233393 & Brazil73D & Brazil/1973 & Human & AY541348 \\
\hline BeAr44824 & Brazil62B & Brazil/1962 & Haemagogus spp. & AY541340 \\
\hline BeAn23536 & Brazil60 & Brazil/1960 & Cebus spp. & AY541338 \\
\hline BeH111 & Brazil54 & Brazil/1954 & Human & AY541335 \\
\hline 614819 & Panama74 & Panama/1974 & Human & AY541412 \\
\hline 35720 & Venezuela98A & Venezuela/1998 & Human & AY541443 \\
\hline SPAr303739 & & Brazil/2010 & Hg. leucocelaenus & \\
\hline
\end{tabular}




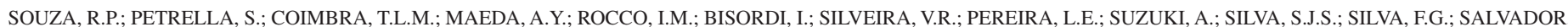
F.S.; TUBAKI, R.M.; MENEZES, R.T.; PEREIRA, M.; BERGO, E.S.; HOFFMANN, R.C.; SPINOLA, R.M.F.; TENGAN, C.H. \& SICILIANO, M.M. - Isolation of Yellow Fever Virus (YFV) from naturally infected Haemagogus (Conopostegus) leucocelaenus (Diptera, Culicidae) in Sao Paulo State, Brazil, 2009. Rev. Inst. Med. Trop. Sao Paulo, 53(3): 133-9, 2011.

retrieved from GenBank and included in the phylogenetic analysis for comparison with the sequence generated in this study (Table 1).

We used the Bayesian inference method available in the software BEAST v. 1.4.6 in order to analyze the phylogenetic relationship of the strains of this study ${ }^{7}$.

Sequences were analyzed using a strict molecular clock model and Bayesian skyline demographic models, considering a constant rate of evolution of $1.0 \times 10^{-4}$ nucleotide substitutions per site per year ${ }^{7}$.

Statistical analysis: From the captured sample, Diversity and Population Dominance indexes were calculated in order to better characterize the mosquito population in the area $\mathrm{a}^{13,20,21}$.

$$
\begin{aligned}
& \text { Margalef's diversity Index: } \\
& \alpha=\frac{\mathrm{s}-1}{\log \mathrm{N}}
\end{aligned}
$$

Where: $\mathrm{S}$ is the number of species sampled and $\mathrm{N}$ is the total number of individuals in all species. Values below 2.0 are representative of areas of low diversity and greater than 5.0 are considered as an indicator of high biodiversity.

Shannon diversity Index:

$$
H^{\prime}=-\sum p_{i} \log p_{i}
$$

Where: $\mathrm{p}_{\mathrm{i}}$ is the proportion of species in relation to the total number of specimens found in surveys.

The Shannon index varies from $0-1,0$ being an indicator of a sample with zero diversity (few species or marked dominance of a few) and 1 indicates a high diversity, with many species and populations numerically equitable.

\section{Simpson dominance Index:}

$\mathrm{D}_{\mathrm{s}}=1-1_{\mathrm{s}}$

being,

$$
1_{\mathrm{s}}=\frac{\sum \mathrm{n}_{\mathrm{i}}\left(\mathrm{n}_{\mathrm{i}}-1\right)}{\mathrm{N}(\mathrm{N}-1)}
$$

Where: $n_{i}$ is the number of individuals of each species and $\mathrm{N}$ is the number of individuals. The Simpson index reflects the probability of two randomly selected individuals in the community belonging to the same species. It varies from 0-1 and higher values indicate a greater probability of individuals being the same species, suggesting great dominance of a single species.

For the species Hg. leucocelaenus, the minimum infection rate (MIR) was calculated, obtained from the division between ${ }^{11,28}$ :

$$
\frac{\text { Positive Pools X } 1,000}{\text { Tested Specimens }}
$$

\section{RESULTS}

The captured mosquitoes were identified and separated in species, number of the specimens, frequency and polls to study (Table 2). Although these data represent a single collecting event, ecological indexes were calculated to better characterize diversity and dominance among the species present in the sample.

Margalef's Diversity Index: $\alpha=4.0$

Shannon Diversity Index $H{ }^{\prime}=0.63$

Simpson's Dominance Index: D $=0.67$

Table 2

Species of mosquitoes captured, April 11-13, Buri, São Paulo, 2009

\begin{tabular}{lccc}
\hline Captured Species & Specimens & $\begin{array}{c}\text { Frequency } \\
\%\end{array}$ & $\begin{array}{c}\text { Pools } \\
\text { No. }\end{array}$ \\
\hline Ochloretatus serratus & 166 & 52.7 & 6 \\
Psorophora ferox/melanota & 24 & 7.6 & 2 \\
Coquiletidia justamansonia & 4 & 1.3 & 3 \\
Sabethes purpureus & 12 & 3.8 & 3 \\
Culex Mel. Sp & 13 & 4.1 & 4 \\
Ochloretatus scapularis & 1 & 0.3 & 1 \\
Psorophora ferox/pseudo & 88 & 28 & 4 \\
Haemagogus leucocelaenus & 6 & 1.9 & 1 \\
Psorophora albipes & 1 & 0.3 & 1 \\
\hline TOTAL & 315 & 100 & 25 \\
\hline
\end{tabular}

Virus isolation (SPAR 303739 strain) was obtained in both Swiss mice, after six days following inoculation, and cell culture from a pool of six specimens of $\mathrm{Hg}$. leucocelaenus mosquitoes. All other pools were negative both in mice and cell culture models. The minimum infection rate $(\mathrm{MIR})$ was calculated at $0.17(\mathrm{MIR}=0.17)$.

It was amplified a product of about 542 nucleotides (NS5-3'UTR region) with semi-nested RT-PCR in 1.7\% agarose gel, ethidium bromide stained. The material was positive to Yellow Fever (Fig.2).

The phylogenetic relationship among this strain and Yellow Fever Virus circulating in South America were reconstructed by Bayesian analysis. The analysis generated a phylogenetic tree (Fig. 3).

The isolated strain sequenced in this study was located in South American I genotype, subclade 1E, coupled with samples of 2008 and 2009 from Brazil and other regions (Fig. 3). The group is strongly supported (posterior probability of 1.00). Internal relations within the subclade, however, are less supported, a factor likely generated by high homology of the samples, which hinders the separation of subgroups.

\section{DISCUSSION}

These data represent a single collection, focusing on a method that facilitates the capture of diurnal species which are attracted by noise or the presence of primates. 


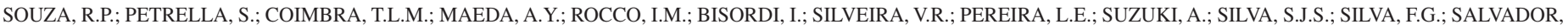

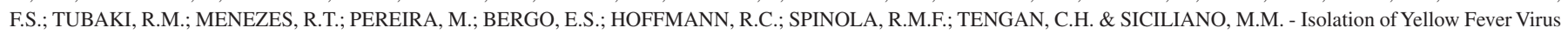
(YFV) from naturally infected Haemagogus (Conopostegus) leucocelaenus (Diptera, Culicidae) in Sao Paulo State, Brazil, 2009. Rev. Inst. Med. Trop. Sao Paulo, 53(3): 133-9, 2011.

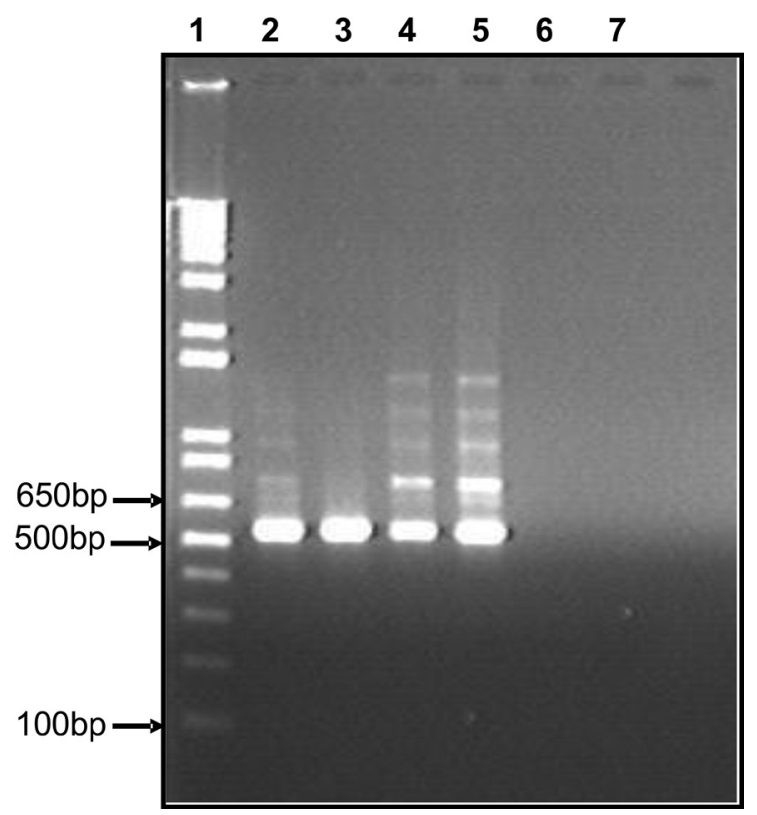

Fig. 2 - Identification of YF amplified product of about 542 nucleotides (NS5-3'UTR region) with semi-nested RT-PCR in $1.7 \%$ agarose gel, ethidium bromide stained. Lane $1=1 \mathrm{~kb}$ plus ladder (Invitrogen); lane $2=$ SPAr 303739, lanes 3 to $5=$ positive control, lanes 6 and $7=$ negative control $(\mathrm{H} 2 \mathrm{O})$.
Although the methodology may represent a bias in ecological analysis, a single collection in a restricted area was performed to try to capture mosquito species involved in transmission of YFV in the region, aiming the virus isolation.

Frequently used ecological indexes were calculated to characterize the sample in relation to diversity and dominance. The Margalef's Diversity Index $(\alpha=4.0)$ and the Shannon Diversity Index $(H '=0.63)$ indicate a sampling of diversity slightly above average, which is expected in a sample from an anthropical environment, in a situation where efforts were focused on capturing specific niches of the population. The absence of mosquitoes typically nocturnal or of crepuscular habits corroborates to the lower diversity. Also the Simpson's Dominance Index $(\mathrm{D}=0.67)$ indicates a pattern of dominance of one or a few species.

This pattern could be observed for the species Ochlerotatus serratus which represented $52.7 \%$ of the species caught and Psorophora ferox / pseudo, accounting for $28 \%$ of sampled specimens (Table 1 ). The relative dominance of these species can be explained by human disturbance of the environment or the effect of the used method, which favors the capture of those mosquito species.

Viral isolation from a pool of $\mathrm{Hg}$. leucocelaenus mosquitoes indicates the natural circulation of YFV in the Buri county, confirming the presence of the virus in São Paulo State. The isolated strain sequenced in this study was located in South American I genotype, coupled with samples of 2008

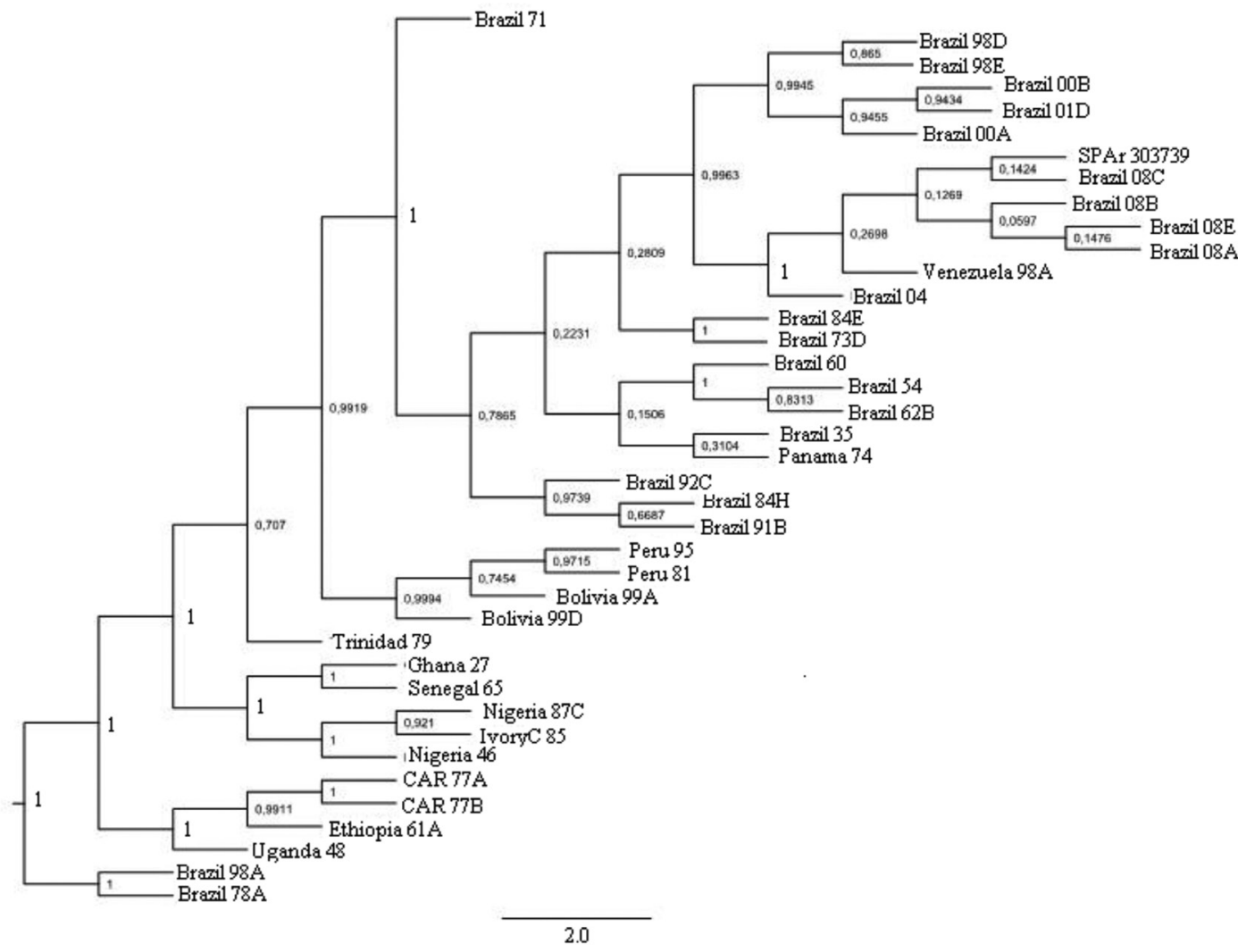

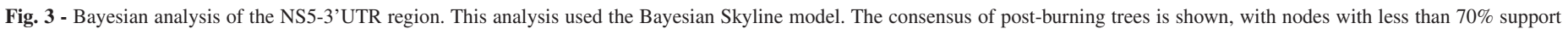
collapsed. Numbers in front of the nodes represent posterior probabilities of those nodes. 


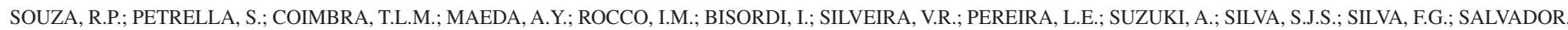
F.S.; TUBAKI, R.M.; MENEZES, R.T.; PEREIRA, M.; BERGO, E.S.; HOFFMANN, R.C.; SPINOLA, R.M.F.; TENGAN, C.H. \& SICILIANO, M.M. - Isolation of Yellow Fever Virus (YFV) from naturally infected Haemagogus (Conopostegus) leucocelaenus (Diptera, Culicidae) in Sao Paulo State, Brazil, 2009. Rev. Inst. Med. Trop. Sao Paulo, 53(3): 133-9, 2011.

and 2009 from Brazil and other regions, representing the continuity of the Epizootic and Epidemic observed elsewhere in Brazil ${ }^{22}$. The isolated strain is strongly associated with the newly described Subclade E1 ${ }^{22}$.

The pool of mosquitoes that led to the virus isolation consisted of six specimens. The minimum infection rate (MIR) was 0.17 . The MIR index is the ratio between the number of positive pools over the total number of mosquitoes tested of each species, by area and period. One limitation of this method ${ }^{10}$ is that the values obtained are valid only for small pools, since the premise of the MIR is the existence of only one infected mosquito per pool. For samples with few individuals, as in this case, and considering that the arboviral infections are rare, the MIR provides the accuracy for this analysis.

The MIR index indicates a probability of about $17 \%$ of $\mathrm{Hg}$. leucocelaenus being infected with YFV. This value is an indicator of the presence of viral activity in the environment. An increase in this index would indicate an impending transmission cycle.

Although the sequence genomic obtained was relatively small and restricted to a highly conserved site at 3 'UT region of the genome were identified, the analysis allowed its initial alignment and recognition among the circulating strains of YFV in Sao Paulo State in 2008. More detailed studies should be the subject of future publications.

Hg. leucocelaenus had previously been found infected in Rio Grande do Sul State ${ }^{27}$ and Colombia ${ }^{4}$. The species was also nominated as a vector in epidemics in Argentina and Bolivia ${ }^{16}$. Their role in the transmission of YFV has been considered secondary up to now in these areas.

This isolation supports the role of this species in the circulation of YFV, as a vector in southern and southeastern Brazil.

The behavior of this species has been described as opportunistic, using multiple sources of food, with most predominantly primatophilic and ornithophilic habits, with capacity for adaptation, including marsupials and rodents in their diet, in places where primates and birds were not available ${ }^{1}$. Although they have been previously described as primarily acrodendrophilic ${ }^{9}$, the studied mosquitoes were captured on the ground level.

The population stratification of different species of Haemagogus has been observed, pointing to Hg. leucocelaenus as a common species in the ground level of Caxiuanã National Forest, Pará, Brazil, mainly in the months of the heaviest rains ${ }^{17}$.

This is the first detection of YFV in Hg. leucocelaenus in São Paulo State. This study indicates the need for continuing surveillance activities, to better understand the behavior of $\mathrm{Hg}$. leucocelaenus and their role in the transmission cycle of YFV in São Paulo State.

\section{RESUMO}

\section{Isolamento do vírus da Febre Amarela de mosquitos naturalmente infectados Haemagogus (Conopostegus) leucocelaenus (Diptera, Culicidae), São Paulo, Brasil, 2009}

Após a detecção de morte de macacos Bugios (gênero Alouatta) e isolamento do vírus da Febre Amarela (YFV) no município de Buri,
Estado de São Paulo, Brasil, foi iniciada uma investigação entomológica em campo. Uma cepa de YFV foi isolada em camundongos recémnascidos e cultura de células de Aedes albopictus - C6/36, a partir de um lote de seis mosquitos Haemagogus (Conopostegus) leucocelaenus ( $\mathrm{Hg}$ leucocelaenus) Dyar \& Shannon coletados no local de estudo. RNA do vírus foi amplificado por RT-PCR e seqüenciado. A topologia gerada indica que a cepa isolada está relacionada ao genótipo South American I, em clado monofilético englobando isolados recentes de epidemias e epizootias entre 2008 e 2009. Análises estatísticas geralmente usadas caracterizaram a amostra em relação à diversidade e dominância, indicando dominância relativa de uma ou poucas espécies. $\mathrm{Hg}$. leucocelaenus foi detectado infectado também no Rio Grande do Sul. No Estado de São Paulo trata-se da primeira detecção do YFV em Hg leucocelaenus.

\section{ACKNOWLEDGMENTS}

The authors wish to thank the directors of the Instituto Adolfo Lutz, Superintendência de Controle de Endemias (SUCEN) and Centro de Vigilância Epidemiológica "Prof. Alexandre Vranjac" of the Secretaria de Estado da Saúde do Estado de São Paulo for their financial and logistical support. The authors wish to thank the Secretaria de Vigilância em Saúde, Ministério da Saúde by the support in field work and the staff of the Núcleo de Doenças de Transmissão Vetorial - Instituto Adolfo Lutz. for their support in the completion of all phases of this research. We extend our thanks to Resolina Pereira Santos of the Núcleo de Cultura de Células - Instituto Adolfo Lutz, for technical assistance in the cell cultures, to Lucy T.A. dos Santos and Regina Celi W.F. Mosetic of the Núcleo de Biotério and our colleagues in the Grupos de Vigilância Epidemiológica (GVEs) who have contributed to the epidemiological surveillance of YF.

\section{REFERENCES}

1. Alencar J, Marcondes CB, Serra-Freire NM, Lorosa ES, Pacheco JB, Guimarães AE. Feeding patterns of Haemagogus capricornii and Haemagogus leucocelaenus (Diptera: Culicidae) in two Brazilian states (Rio de Janeiro and Goiás). J Med Entomol. 2008;45:873-6.

2. Beaty B, Calisher CH, Shope RE. Arboviruses. In: Schimidt NJ, Emmons RW, editors. Diagnostic procedures for viral, rickettsial and chlamydial infections. $6^{\text {th }} \mathrm{ed}$ Washington: American Public Health Association; 1989. p. 797-855.

3. Bugher JC, Boshell-Manrique J, Garcia MR, Gilmore RM. Susceptibility to yellow fever of vertebrates of eastern Colombia. Am J Trop Med Hyg. 1941;21:309-33.

4. Casals J. Immunological technique for animal viruses. In: Moramorosh K, Koprowski H, editors. Methods in Virology. New York: Academic Press; 1967. p. 175-181.

5. Deubel V, Huerre M, Cathomas G, Drouet MT, Wuscher N, Le Guenno B. Molecular detection and characterization of yellow fever virus in blood and liver specimens of a non-vaccinated fatal human case. J Med Virol. 1997;53:212-7.

6. Divisão de Zoonoses do Centro de Vigilância Epidemiológica "Prof. Alexandre Vranjac", Coordenadoria de Controle de Doenças da Secretaria de Estado da Saúde de São Paulo (DZ/CVE/CCD/SES-SP). Casos de febre amarela silvestre em residentes do Estado de São Paulo, 2007 - 2008. Bol Epidemiol Paulista. 2008;5:12-5.

7. Drummond AJ, Rambaut A. BEAST: Bayesian evolutionary analysis by sampling trees. BMC Evol Biol. 2007;7:214

8. Filippis AMB, Nogueira RMR, Schatzmayr HG, Tavares DS, Jabor AV, Diniz SC. Outbreak of jaundice and hemorrhagic fever in the Southeast of Brazil in 2001: detection and molecular characterization of yellow fever virus. J Med Virol. 2002;68:620-7 


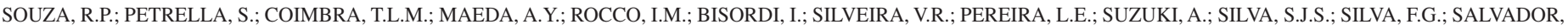

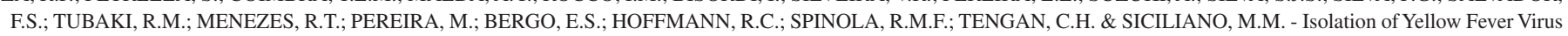
(YFV) from naturally infected Haemagogus (Conopostegus) leucocelaenus (Diptera, Culicidae) in Sao Paulo State, Brazil, 2009. Rev. Inst. Med. Trop. Sao Paulo, 53(3): 133-9, 2011.

9. Forattini OP. Entomologia médica. São Paulo: Edusp, 1965. v. 3.

10. Fundação Nacional de Saúde (FUNASA). Manual de vigilância epidemiológica de febre amarela. Brasília: Ministério da Saúde, Fundação Nacional de Saúde; 2005.

11. Gu W, Lampman R, Novak RJ. Problems in estimating mosquito infection rates using minimum infection rate. J Med Entomol. 2001;40:595-6.

12. Igarashi A. Isolation of a Singh's Aedes albopictus cell line clone sensitive to dengue and chikungunya virus. J Gen Virol. 1978;40:531-44.

13. Margalef R. Diversidad de especies en las comunidades naturales. Publ Inst Biol Apl. 1951;6:59-72.

14. Ministério da Saúde. Secretaria de Vigilância em Saúde. Guia de vigilância epidemiológica. 6a ed. Brasília: Ministério da Saúde; 2005.

15. Monath TP. Yellow fever. In: Monath TP, editor. Arboviruses: ecology and epidemiology. Boca Raton; CRC Press, 1988. v.5, p. 139-241.

16. Monath TP. Yellow fever: an update. Lancet. 2001;1:11-20.

17. Pinto CS, Confalonieri UEC, Mascarenhas BM. Ecology of Haemagogus sp. and Sabethes sp. (Diptera: Culicidae) in relation to the microclimates of the Caxiuanã National Forest, Pará Brazil. Mem Inst Oswaldo Cruz. 2009;104:592-8.

18. Ribeiro MAR. História sem fim: inventário da saúde pública, São Paulo, 1880-1930. São Paulo: UNESP; 1993.

19. Rocco IM, Katz G, Tubaki RM. Febre amarela silvestre no Estado de São Paulo: casos humanos autóctones. Rev Inst Adolfo Luz. 2003;62:201-6.
20. Shannon CE, Weaver W. The Mathematical theory of communication. Urbana: University of Illinois Press; 1998.

21. Simpson EH. Measurement of diversity. Nature. 1949;163:688.

22. Souza RP, Foster PG, Sallum MA, Coimbtra TL, Maeda AY, Silveira VR et al. Detection of a new yellow fever virus lineage within the South American genotype I in Brazil. J Med Virol. 2010;82:175-85.

23. Teixeira LA. Da transmissão hídrica a culicidiana: a febre amarela na sociedade de medicina e cirurgia de São Paulo. Rev Bras Hist. 2001;21:217-42.

24. Travassos da Rosa APA, Travassos da Rosa ES, Travassos da Rosa JFS, Degallier $\mathrm{N}$, Vasconcelos PFC, Rodrigues SG, et al. Os arbovírus no Brasil: generalidades, métodos e técnicas de estudo. Belém: Instituto Evandro Chagas; 1994.

25. Travassos da Rosa APA, Vasconcelos PFC, Travassos da Rosa ES, Rodrigues SG, Mondet B, Cruz AC, et al. Dengue epidemic in Belém, Pará, Brazil, 1996-97. Emerg Infect Dis. 2000;6:298-301.

26. Vasconcelos PFC, Travassos da Rosa APA, Pinheiro FP, Rodrigues SG, Travassos da Rosa ES, Cruz AC, et al. Aedes aegypti, dengue and re-urbanization of yellow fever in Brazil and other South American countries-past and present situation and future perspectives. WHO Dengue Bull (New Delhi). 1999;23:55-66.

27. Vasconcelos PFC, Sperb AF, Monteiro HAO, Torres MAN, Souza MRS, Vasconcelos $\mathrm{HB}$, et al. Isolations of yellow fever virus from Haemagogus leucocelaenus in Rio Grande do Sul State, Brazil. Trans R Soc Trop Med Hyg. 2003; 97: 60-2.

28. Walter SD, Hildreth SW, Beaty BJ. Estimation of infection rates in population of organisms using pools of variable size. Am J Epidemiol. 1980;112:124-8.

Received: 24 August 2010

Accepted: 25 April 2011. 


\section{LIBRARY OF THE SÃO PAULO INSTITUTE OF TROPICAL MEDICINE}

Website: www.imt.usp.br/portal

Address: Biblioteca do Instituto de Medicina Tropical de São Paulo da Universidade de São Paulo Av. Dr. Enéas de Carvalho Aguiar, 470. Prédio 1 - Andar térreo.

05403-000 São Paulo, SP, Brazil.

Telephone: 5511 3061-7003 - Fax: 5511 3062-2174

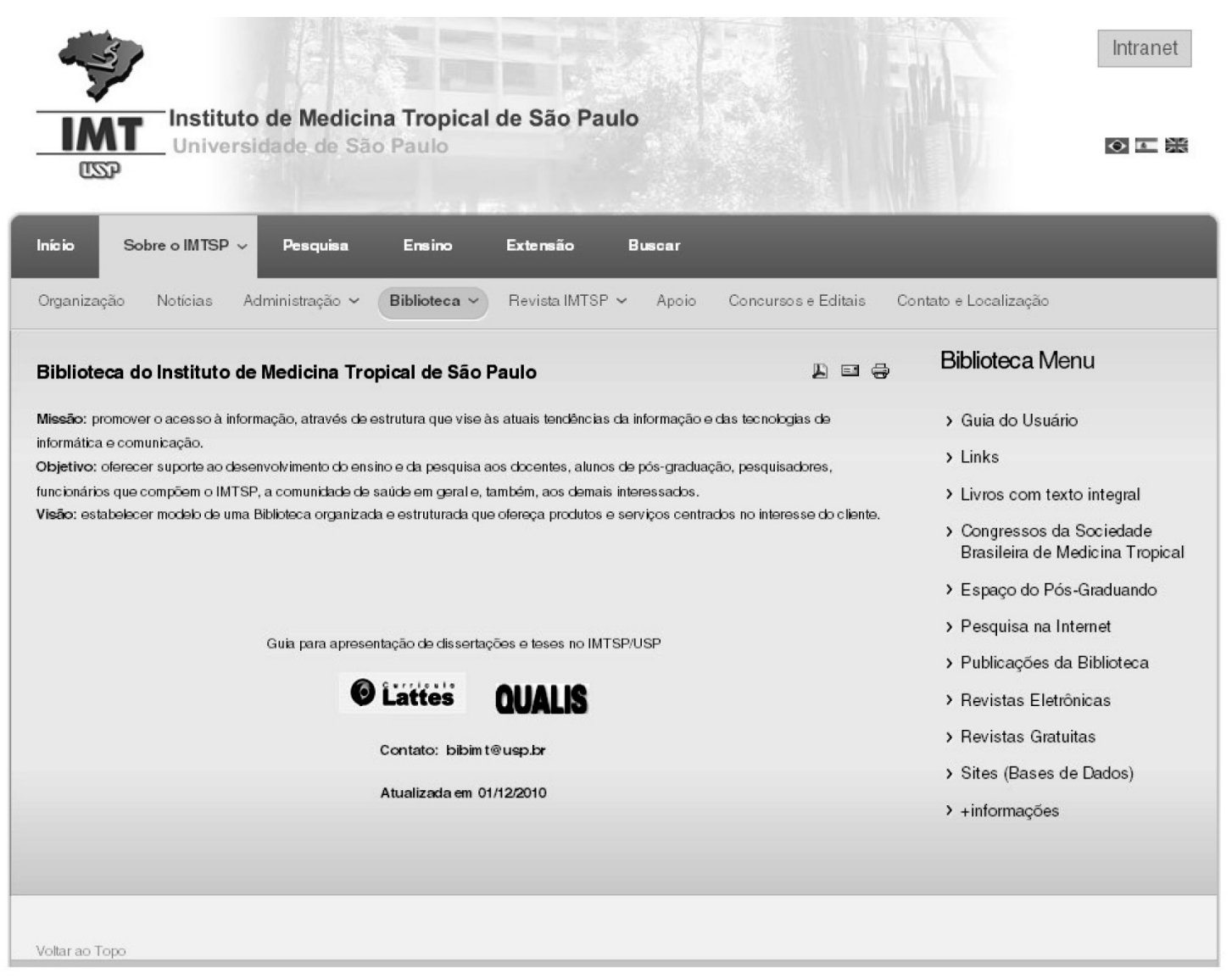

The Library of the São Paulo Institute of Tropical Medicine (IMTSP Library) was created on January 15,1959 in order to serve all those who are interested in tropical diseases. To reach this objective, we select and acquire by donation and / or exchange appropriate material to be used by researchers and we maintain interchange between Institutions thorough the Journal of the São Paulo Institute of Tropical Medicine, since the Library has no funds to build its own patrimony.

The IMTSP Library has a patrimony consisting of books, theses, annals of congresses, journals, and reference works.

The collection fo journals existing in the Library can be verified through the USP - Bibliographic Database - OPAC - DEDALUS http://dedalus.usp.br:4500/ALEPH/eng/USP/USP/DEDALUS/start of the USP network. 